大阪大学医学部第 3 解剖学教室 (主任: 黑津敏行呚授).

3rd Dept. of Anat., Osaka Univ. Med. School (Director: T. KUROTSU).

\title{
家鬼の下垂体前葉に認められる神経分泌顆粒。
}

$$
\text { につゃて** }
$$

\section{On the Neurosecretory granules in the Anterior Pituitary Gland of Rabbits.}

\author{
岡 田 正 雄 Masao OKADA.
}

〔昭和 30 年 4 月 8 日原稿受付.〕

Bargm $: n n$ （1949）以来神経分泌現象の面から視床下部-下垂体系が種々 再検討され，最近では従来の後葉ホルモン様作用物質は視床下部の2-3の 神経核で生産され，これが視床下部下垂体神経束に沿って後葉に輸送さ れると考えられるようになった。このようと神経分泌現象による視床下部 と下垂体後葉との関連性は，原則的にほ心゙明かになったと思われるが，下 垂体前葉とどのような機能的或は形態学的関連を持っているかに就いては 未だ決定的の知見がない，殊飞最近では，前葉の分泌機能は自律神経線維 飞依って直接支配されるのではなく，寧ろ視床下部で造られる生理的活性 物質によって左右されるという見解が有力になって来たので，私はこの見 地から, 神経分泌顆粒と前葉との関係を形態学的に追求し, 視床下部によ る前葉支配の機構を推知し得る興味ある所見を認めたので報告する。

\section{I. 実験材料と方法.}

成熟雄性家鬼（20匹）の1群を Bouin 氏液或は Zenker-Formol 液で生 体固定し，他の 1 群は空気栓塞で死亡せしめて後, 直ちに漏斗及び下垂体 荎と共に下垂体を摘出し，更飞 Bouin 氏液で 1-2 日間再固定した。次に 所定の操作で矢状断による $6 \mu$ のパラフィン連続切片となし，Halmi 氏法 （1952）の変法により染色標本を作製した。この場合微細な分泌顆粒を追 求し易いようと抗染を出来るだけ淡くした。

\section{II. 自 家 所見.}

1. 漏斗及び下垂体茎を経て隆起部とこれに接する前葉に至る経路.

漏斗及び下垂体茎の外層部とこれに接する隆起部には，極めて豊富な毛 細血管網があり，この血管網より漏斗及び茎内に深く特殊血管が入り込み，

\footnotetext{
* 本論文の要旨は昭和 30 年 4 月 日本解剖学会総会で追加発表した.
} 
これらによって所謂下垂体門脈系の第 1 次ループが形成されているが，こ ১から発した血管群は脽葉内深く浸入して第 2 次ループを形成している。 大小種々の所謂神経分泌頪粘は，漏斗及び下垂休茥では視床下部一垂体 線維束に针って後葉まで多数理っているが，その一部は、記門脈系の第 1

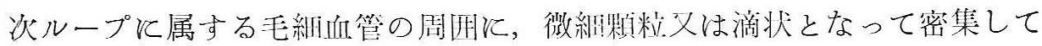
いる（Fig. 1 と 3）。同時江又一部の微細顆粒は，特殊血管内に大きい丸い

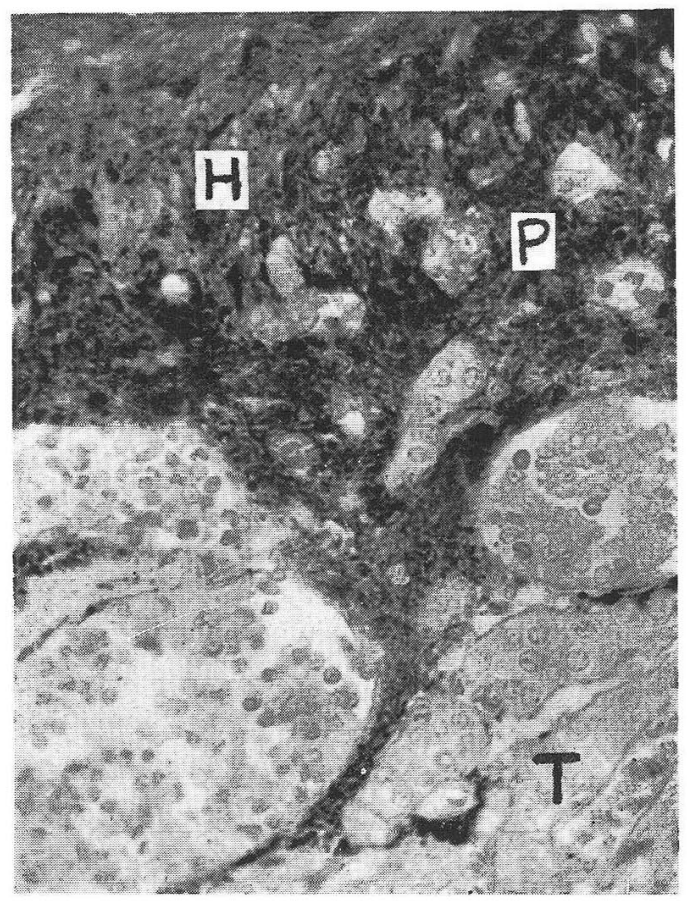

Fig. 1. Sagittal section through the pituitary stalk showing the numerous neurosecretory granules entered into the perivascular spaces of the hypophysial portal system. H the hypothalamo-hypophysial neurosecretory tract, $\mathbf{P}$ the clustered capillaries of the portal vessels, $\mathbf{T}$ pars tuberalis. ca. $\times 250$.

膠様滴となって人っているものや（Fig. 2)，或は微細顆料のま」で多数入

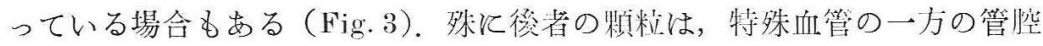
（多分輸出管と思われる）飞のみ認められ，しかもこの血管が漏斗或は茎

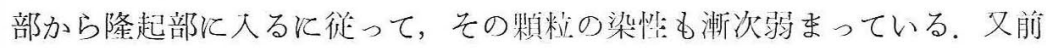
葉内部の門脈血管内には淡染恻:の大きい膠様滴もみとめられることがある (Fig. 4)。この様な像から下垂体爻部で抜出した神経分泌顆粒の一部は, 


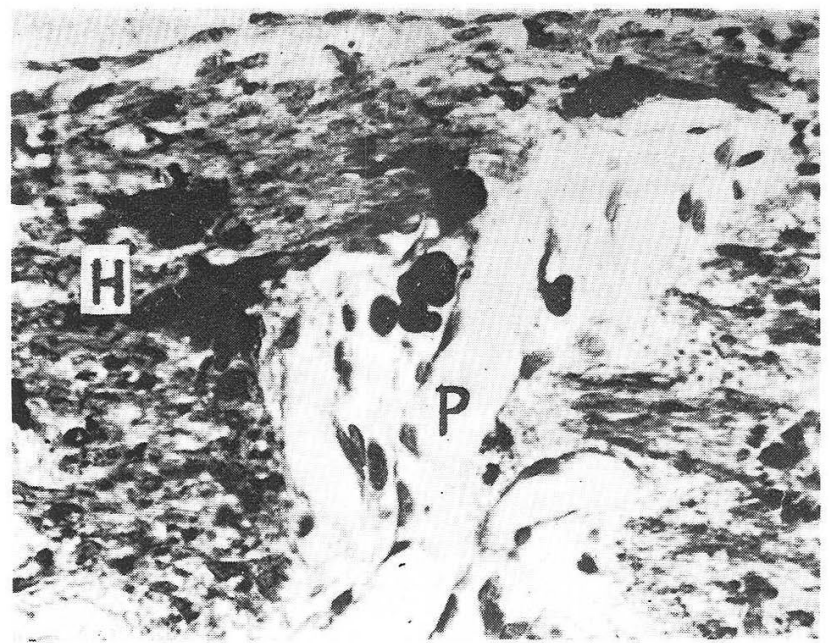

Fig. 2. Sagittal section through the hypophysial stalk showing the neurosecretory fibers and the colloid-like neurosecretory substance in the primary capillary loops of the hypophysial portal vessels. H the hypothalamo-hypophysial neurosecretory tract, $\mathbf{P}$ the primary capillary loops of the portal system. ca. $\times 500$.

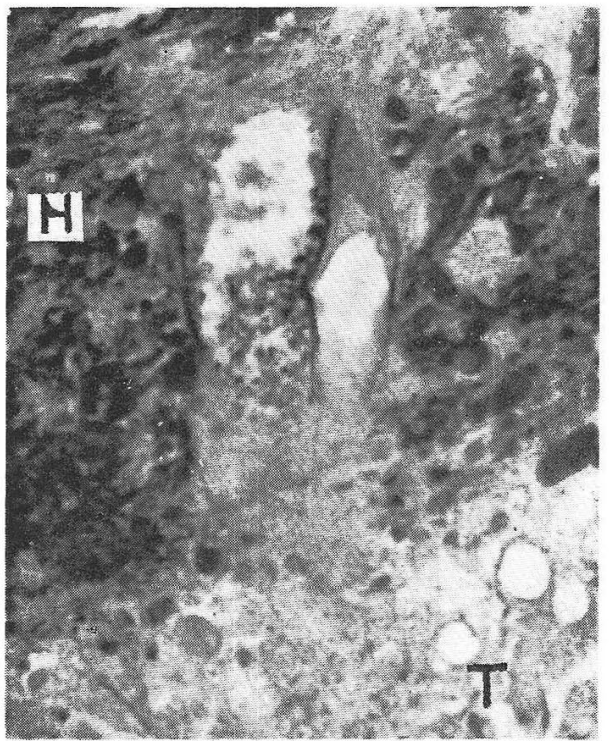

Fig. 3. Sagittal section through the pituitary stalk showing the numerous neurosecretory granules in the primary capillary loops of the hypophysial portal vessels. $\mathbf{H}$ the hypothalamo-hypophysial neurosecretory tract, $\mathbf{T}$ pars tuberalis. ca. $\times 500$. 


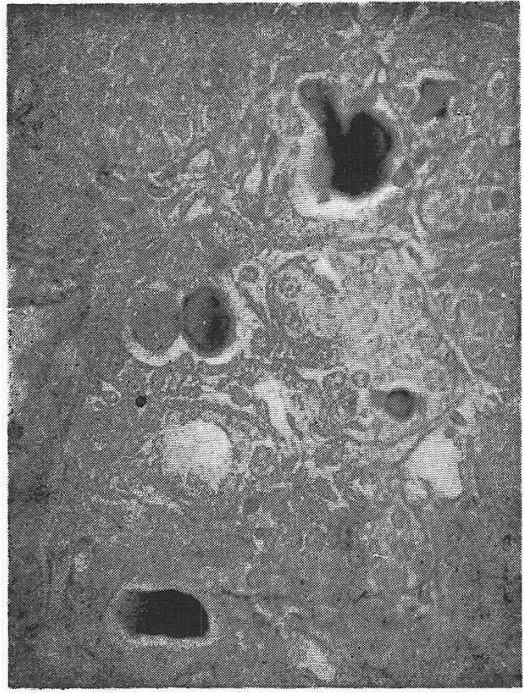

Fig. 4. Sagittal section of the frontal part of the pars distalis showing the colloid-like substance in the portal system. ca. $\times 250$.
特殊血管か或は䒝外層部の毛紐血 管䦌閁より血液内飞排出され，次 第に隆起部から前葉内に送られる 有のと思われる。

又漏斗及び下体体茎の外酋部の 毛縕血管周囲飞集った顆精群の一 部は，この血管壁に浚ってその走 行に街い，隆起部から前葉内に侵 大し次第飞消失するが (Fig. 1 と 5)，時には消失するととなく前葉 の内部に深く入り込えでいる場合 もある(Fig. 6)。このような像か ら神経分泌顆䊀の一部は恐らく, 格子線維系で出来た門脈系のVirchow-Robin 氏腔（佐野 1955）内 代 を流れて前渠と入るものと思われ る。更汇隆起部とこれと近い㓩葉

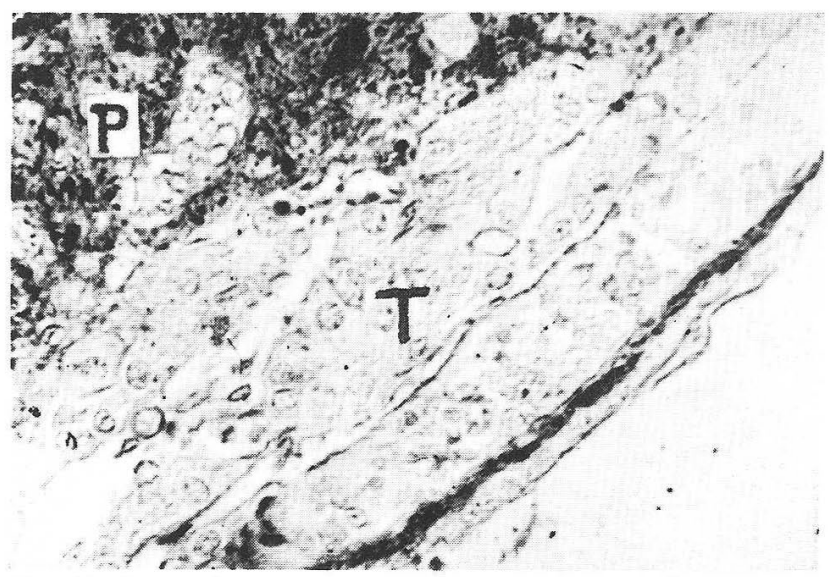

Fig. 5. Sagittal section through the pars tuberalis showing the neurosecretory granules along the portal vessels which run from the infundibulum towards the pars distalis. $T$ the upper part of pars tuberalis, $\boldsymbol{P}$ the clustered capillaries of the portal system. ca. $\times 300$.

の腺細胞間隙内に，同じ染怆の微小顆䊀が点線状，連珠状又は散在的に大 り込み，屡々や」大きな滴状を形成しているものもある（Fig. 7)。この様 


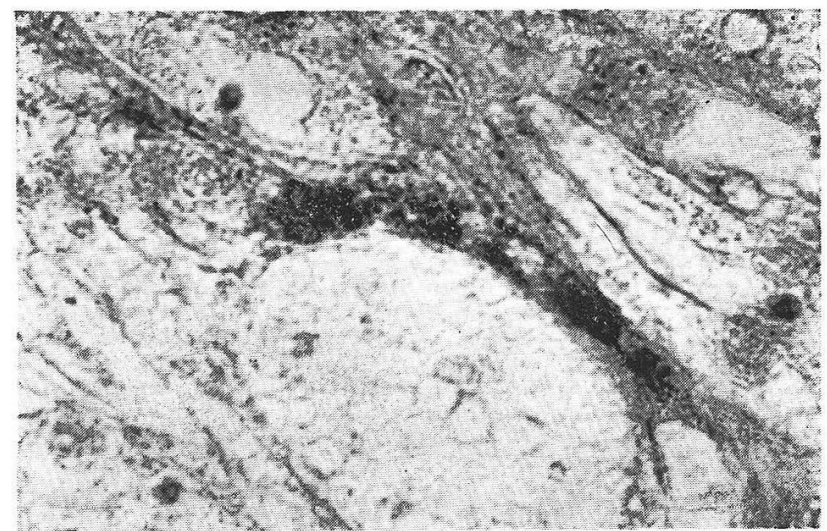

Fig. 6. Sagittal section through the frontal part of the pars distalis showing the fine granules in the perivascular spaces. ca. $\times 750$.

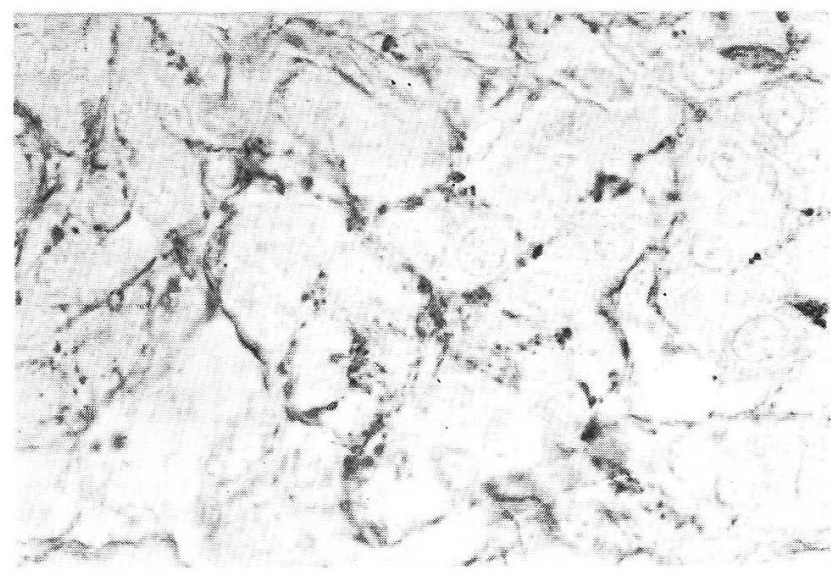

Fig. 7. Sagittal section through the frontal part of the pars distalis showing the fine neurosecretory granules in the intercellular spaces of the anterior pituitary gland. ca. $\times 750$.

な顆粒は腺細胞内には企く贸められないし，腺絸胞によって分泌される所 見も，更に又前葉の 3 種の細胞のどれかと特に形態学的に関係があると思 われる像を認めなかった。尚其の星は漏斗及び下平体茎から㸕ざかる程減 少を示している。この栐な所見から，腺紐肘間隙飞認められる顆粘は矢張 り漏斗又は下更体莘から侵入したものと思われる。(Fig. 8 のa). 


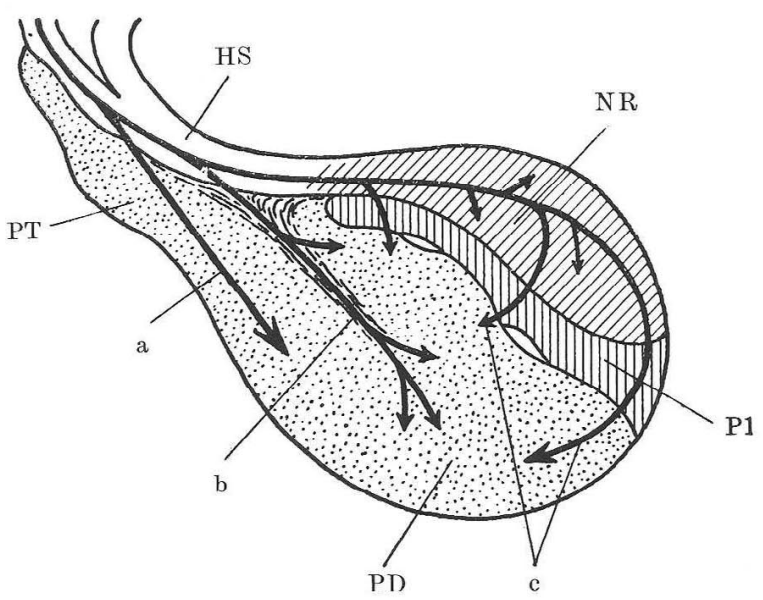

Fig. 8. Scheme of a median section through the hypophysis of a rabbit showing the neurosecretory pathways from the hypothalamo-neurohypophysial system to the anterior pituitary gland. HS pituitary stalk, NR pars nervosa, PT pars tuberalis, $\mathbf{P D}$ pars distalis, $\mathbf{P I}$ pars intermedia, $\mathbf{a}, \mathbf{b}, \mathbf{c}$ the neurosecretory pathways to the anterior pituitary gland.

2. 下垂体觉外層部より直接闫染中心部に人る徍路.

尾生学的飞異る下更休羍と㣪葉，また隆起部と澗葉の間には，本質的

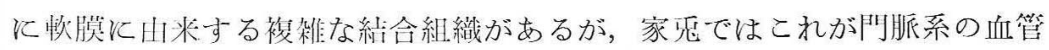
の一部を伴い，1つの層をなし隆起部と中間葉との間を们荣の中心部に问

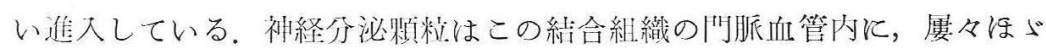
速絖的に認められるし，又この結合組織の周四にある腺細胞間隙にも，1. の埸合と同様飞速珠状，点線状或は散在的飞侵入している像が認められる. このことから神経分泌顆粘の・部は門脈血管の一部を介して直接前葉小心 部の細胞間隙送られるものと考学る（Fig.8のb）。

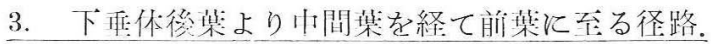

多数の微小顆粒と小数の小滴状顆粘は，後葉より点線状或は連珠状をな

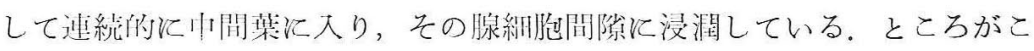

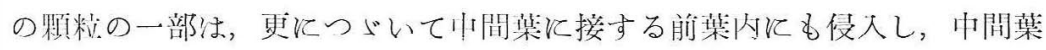

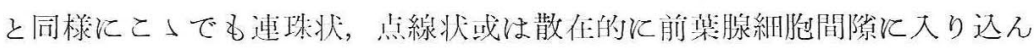
でいる（Fig. 9)。この場合門㷛と似て血管内在連ばれて来た像はなく，

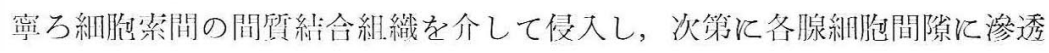

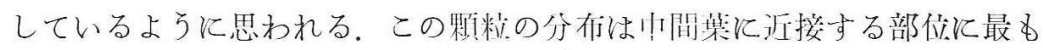
多く，離れるに良って次第飞減少し消失与る。矢状断切片でみると，下垂 


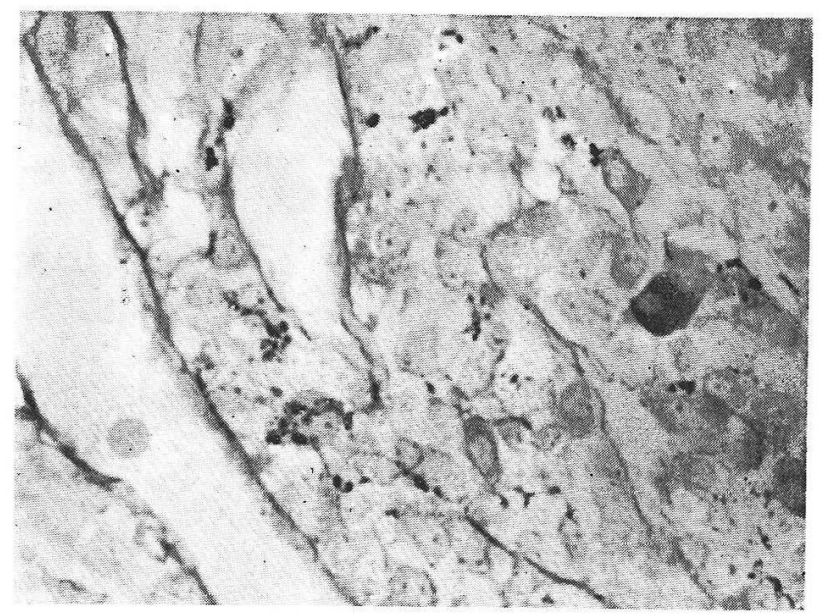

Fig. 9. The fine granules which entered from the posterior lobe to the pars distalis via pars intermedia, are found in the intercellular spaces of the anterior pituitary gland. ca. $\times 300$.

体の最尾端部は前葉と中間葉との境界がや」不明暸であるが，顆粒の前葉 内侵入量はこの部分飞最も著明である。この顆粒は又削記と同様飞矢張り 腺細胞体内には思められず，腺細胞によって分泌される听見も，或は又前 葉の３種の細胞のどれかと特に形態学的に関連のある像をも認めなかった。

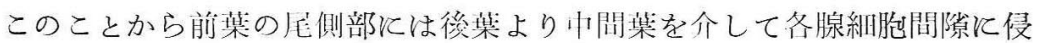
入しているものと考光る(Fig.8のの).

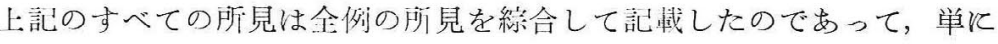
1 例だけで総ての徍路を認め得るとけ限らない，殊に血管内の顆稤は生体 固定を施したものでは比較的認め難い.

\section{III. 総 括と考察.}

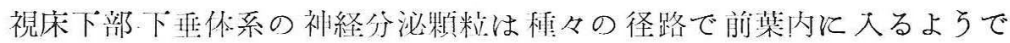
ある。即ち前葉の㕫側部には漏斗灭び下留体茥部より門脈系の血管内或は その脈管外通液路を通って大り，前染の山心部には羍外層部から前葉内に 入る太い結合組織内の門脈系血管を介し，前集の尾側部では後葉より中間

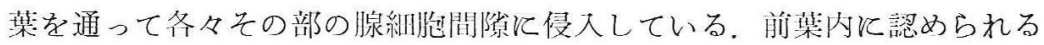
顆粘は荠部或は中問集から離れるにつれて減少子示す。又前葉内のこの顆 粓は腺組胞休内に認められず，又腺細胞によって分泌される所見も，或は 又 3 種の腺細胞のどれかと形態学的に特別に関連した像も認めなかった。 
視床下部から下垂体後葉に走る神経分泌線維は，漏斗及び下垂体茎部で 門脈系（Popa と Fielding 1930, Wislocki と King 1936) の第1次ループ 飞属する血管群飞密接し或は迁曲して走るが (Palay 1953, Benoit と Assenmacher 1953)，屡々血管壁飞混入するすのや（Bargmann 等 1950), 血管 壁飞終るものもある (Green 1951, Palay 1953, Dawson 1953). 而もこの分 泌顆粒は丁度後葉内の血管周囲飞認められるょうと，この部の血管周囲飞 も多数集っていることが明かである（Benoit と Assenmacher 1953, Schimazu 等 1954, Imai 1954). この様な所見から最近では, 神経分泌顆粒の 一部は恐らく下垂体荎で門脈系の第 1 次ループに入るるのと推定されてい るが，私は明かに排出されている像を認めた。

ところが上記門脈系の血流飞ついては，かつて云われた様な前葉より視 床下部への上向き（Pora と Fielding 1930）ではなく，寧ろ視床下部より 前葉への下向きであるとされている（Wislocki と King 1936, Green と Harris 1949, Green 1951, 大藤 1953). 私は特殊血管内に入った微小顆粒 が次等に色調を失いつ〉連続的に前葉内に入るものをみた。 或は又特殊血 管内の膠様滴も同様飞淡染性となったものを前葉内の血管に認めたから, 上記血流方向とも考兄合せて，分泌顆粒が前葉に送られるものと推定して いる.

次にこの門脈系の第 1 次ループをなす血管群には洞様格子線維系からな るVirchow-Robin 氏腔があり（佐野 1955），又前葉内でも格子線維網格が 脈管外通液路を形成しているから（坂井田 1947），私のみた血管周囲飞沿 って前葉内に入る顆粒は上記通液路を通るものであるう。それ故下垂体荎 より前葉内に入る顆粒は門脈系の第 1 次ループの血管腔とその脈管外通液 路の両者を介するものと考兵る。

後葉より中間葉に大る神経線維の存在は確認されているし（Green 1947, 1951), 又同時飞神経分泌顆粒が侵入することも, 多数の研栄者によって 報告されているが（Bargmann 1949, Bargmann 等 1950, Hild 1.951, Scharrer 1952, Dawson 1953, Palay 1953, 野田と佐野 1955), 前葉内飞 侵大している像は未だ認められていない。私の所見では一部の顆粒は明か そ中間葉を経て前葉の腺細胞間隙に侵入している。けれどもこれが神経線 維に沿って大るか否かは実証しえない，以上から視床下部でっくられる神 経分泌顆精が恐らく門脈系を介して前葉に入り，これが前葉の機能を支配 するのであるうという仮説を(Bargmann 1953, Benoit と Assenmacher 1953, Palay 1953, E と B. Scharrer 1954, Imai 1954), 私は更飞有力にし 得たと思うし，更に又門脈系だけでなく後葉から中間葉を介して前葉に入 
る顆粒もあって，これも前葉の機能の一部を支配するものではなかろうか. 又近来活潑に行われている排卵のホルモン㑉節飞対する視床下部の意義 飞関する研究や（黒津等 1949，Kurotsu 等 1950, 1952, Markee等 1952, 小林 1952，1953，Harris 1953)，漏斗部及び下垂体自体の電気刺戟による ACTH の放出飞関する研究 (De Groot 1952) 等も亦この方面から或程度合 理的飞解釈し得るものと考兄る. 特飞視床下部の黒津のB-交感带を刺戟す ると前葉ホルモンの排出が行われて，排卵，精子の排出，副㫮皮質と髄質 のホルモン分泌や甲状線のコロイド排出等が認められるが（Kurotsu 等 1950，1952，黒津 1953，中村 1954），これと期を一にして対照動物の後葉 及び下垂体茎部に認められた神経分泌顆粒が著しく減少することは（Schi$\mathrm{mazu}$ 等 1954), 私の所見と考兄合せて，この顆粒が恐らく前葉の腺機能を 支配する一要素であろうとの見解を一層強くするものである.

然し少数の研究者は前葉に対する視床下部の支配が門脈系を介して行わ れることに反対しているが (Zuckermann 1954)，いずれとしても更にこの 方面の実験形態学的追求が必要である.

\section{IV. 結語.}

家鬼を用い，視床下部-下垂体後葉系の神経分泌と前葉との関係を Halmi 氏染色法の変法によって追求した。

1. 視床下部より下る神経分泌顆粒の一部が，漏斗及び下垂体茎外層部 の門脈系の血管群及びその脈管外通液路を通って, 隆起部及び前葉の吻側 部と中心部の腺細胞間隙に侵入する像を認めた。

2. 後葉より中間葉に侵大する神経分泌顆粒の一部が，前葉の尾側部の 腺細胞間隙飞侵入する像を認めた。

3. 前葉内に侵入した顆粒は下垂体茎又は中間葉から離れる程減少し, 漸次消失する。

4. 以上の所見は視床下部の神経分泌物質が下垂体前葉の腺機能を支配 するという仮説と形態学的根拠を与えたことになる。

終りに臨み, 終始御㸸切な御指導を賜りました黑津教授, 伴助教授に深謝致します.

\section{Author's Abstract.}

The relationship of the neurosecretory system to the anterior pituitary gland was investigated bei rabbits by a modification of HALMI's staining. The results were as follows:

Some neurosecretory granules of the hypothalamo-hpyophysial neurosecretory fibers enter into the intercellular spaces of the pars tuberalis 
and of the frontal half part of the pars distalis via the primary blood capillaries of the hypophysial portal system and their perivascular spaces.

Some neurosecretory granules enter into the intercellular spaces in the caudal half part of the pars distalis via the pars intermedia from the pars nervosa.

The hypothesis that the hypothalamic neurosecretory material controls the function of the anterior pituitary gland, is therefore from the morphological view point much more supported.

\section{文献。}

Bargmann, W.: Über die neurosekretorische Verknüpfung von Hypothalamus und Hypophyse. Klin. Wschr. 27 (1949). S. 617. - Zwischenhirn und Hypophyse. Arch. Gynäk. 183 (1953). S. 14. - Bargmann, W., W. Hild, R. Ortmann u. Th. H. Schiebler: Morphologische und experimentelle Untersuchungen über das hypothalamische hypophysäre System. Acta neuroveg. 1 (1950). S. 233. - Benoit, J. et I. Assenmacher: Rapport entre la stimulation sexuelle préhypophysaire et la neurosécrétion chez l'oiseu. Arch. Anat. mic. et Morph. exp. 42 (1953). P. 334. - Dawson, A.B. : Evidence for the termination of neurosecretory fibers within the pars intermedia of the hypophysis of the Frog, rana pipiens. Anat. Rec. 115 (1953). P. 63. - De Groot, J. : The significance of the hypophysial portal system. 1952. - Green, J.D.: Vessels and nerves of the amphibian hypophysis. A study of the living circulation and of the histology of the hypophysial vessels and nerves. Anat. Rec. 99 (1947). P. 21. - The comparative anatomy of the hypophysis, with special reference to its blood supply and innervation. Amer. J. Anat. 88 (1951). P. 225. - Green, J.D. a. W. Harris: Observation of the hypophysio-portal vessels of the living rat. J. Physiol. 108 (1949). P. 359. - Halmi, N. S.: Differentiation of two types of basophiles in the adenohypophysis of the rat and the mouse. Stain Techn. 27 (1952). P. 61. - Harris, G.W.: The physio$\log y$ of the hypothalamus and pituitary gland in relationship to gynaecology. Arch. Gynäk. 183 (1953). P. 35. - Hild, W.: Vergleichende Untersuchungen über Neurosekretion in Zwischenhirn von Amphibien und Reptilien. Z. Anat. u. Entw. 115 (1951). S. 459. - Imai, K.: Some observations on the hypothalamo-hypophyseal neurosecretory system in the albino rat. Gumma J. med. Sci. 3 (1954). P. 281. 一 小林隆：間脳下垂体系と性機能. 内分泌のつどい. 1 (1952). 頁 169. 一間脳一下垂体-卵巢系. 最新医学. 8(1953). 頁 1256. 一黒津敏 行：自律中樞と内分泌臟器との相互関係. 日新医学. 40 (1953). 頁 533. 一黑津续行, 蒼智敬一, 伴忠康 : 性中樞飞関する見解の整理. 脳研究. 5 (1949). 頁 1. 一 Kurotsu, T., K. Kurachi a. T. Ban : Experimental studies on ovulation by the electrical stimulation of the hypothalamus of rabbits. Med. J. Osaka Univ. 2 (1950). P. 1. - Kurotsu, T., K. Kurachi, C. Tabayashi a. T. Ban : Fxperimental studies on ovulation by the electrical stimulation of the hypothalamus of hypophysectomized rabbits. Med. J. Osaka Univ. 3 (1952). P. 139. - Markee, J.E., J.W. Everett a. C. H. Sawyer: The relationship of the nervous system 
to the release of gonadotrophin and the regulation of the sex cycle. Rec. Progr. Hormone Res. 7 (1952). P. 139. 一 中村忠雄：自律中枢の電気刺戟による睪丸の 組織学的変化について. 阪大医誌. 6 (1954). P. 515. 一野田秀俊と佐野 豊 : Neurosecret の血管内及び中葉内浸潤. 解剖誌. 30 (1955). 頁 55. 一 大藤 真 : 間脳-下 垂体系に於ける下垂体門脈. 最新医学. 8 (1953). 頁 1110. - Palay, S. L. : Neurosecretory phenomena in the hypothalamo-hypophysial system of man and monkey. Amer. J. Anat. 93 (1953). P. 107. - Popa, G. a. U. Fielding : The vascular link between the pituitary and the hypothalamus. Lancet, 2 (1930)．Ｐ． 238． 一 坂井田いずみ：脳下垂体に於ける通液路と網狀線維との関係. 解剖誌. 23 (1947). 頁 45. 一 佐野 豊 : 視床下部一下垂体系(人)に括ける 1 亜系と しての結合組織, 特飞格子線維組織の研究. 日組録. 7 (1955). 頁621. - Scharrer, E.: Das Hypophysen-Zwischenhirn-systen von Syllium stellare. Z. Zellforsch. 37 (1952). S. 196. - Scharrer, E. u. B. : Neurosekretion. Möllendorffs Handbuch der mikroskopischen Anatomie des Menschen. Bd. 6, Tl. 5. Berlin, Springer. 1954. - Shimazu, K., M. Okada, T. Ban a. T. Kurotsu : Influence of stimulation of the hypothalamic nuclei upon the neurosecretory system in the hypothalamus and the neurohypophysis of rabbit. Med. J. Osaka Univ. 5 (1954). P. 701. - Wislocki, G. B. a. L. S. King: The permeability of the hypophysis and hypothalamus to vital dyes, with a study of the hypophysial vascular supply. Amer. J. Anat. 58 (1936). P. 421. - Zuckermann, S. : Hypothalamic anterior pituitary relations. Pubbl. Staz. zool. Napoli. 24 (Suppl.) (1954). P. 21. 